\title{
$X$-chromosome activity in the germ cells of Sex-reversed mouse embryos
}

\author{
Anne McLaren and Marilyn Monk \\ M.R.C. Mammalian Development Unit, Wolfson House, 4 Stephenson Way, \\ London NWI $2 H E, U . K$.
}

\begin{abstract}
Summary. Germ cells were isolated from $\mathrm{XX}$ ovaries and $\mathrm{XY}$ and $\mathrm{XX}$ Sex-reversed $(\mathrm{S} x \mathrm{r} /+)$ testes of mouse embryos 14-16 days post coitum, and the activity of an $\mathrm{X}$-chromosome-coded enzyme, hypoxanthine phosphoribosyl transferase (HPRT), relative to an autosomal one, adenine phosphoribosyl transferase was determined. The ratio of enzyme activities in $\mathrm{XX} \mathrm{Sxr} /+$ prospermatogonia was significantly higher than that in XY prospermatogonia, up to 2-fold, suggesting that the silent $\mathrm{X}$ chromosome is reactivated in XX male germ cells before birth, as it is in female germ cells. The ratio was several times higher still in $\mathrm{XX}$ oocytes than in $\mathrm{XX}$ prospermatogonia, confirming that the increase in HPRT activity reported in oocytes is only partly due to an $\mathrm{X}$-chromosome dosage effect.
\end{abstract}

\section{Introduction}

The dominant autosomal gene Sex-reversed ( $S x r$ ) causes $\mathrm{XX}$ individuals to develop as phenotypic males (Cattanach, Pollard \& Hawkes, 1971). A few of the XX Sxr/+ germ cells enter the prophase of meiosis before birth (McLaren, 1981), as do XX germ cells in the mouse ovary; these tend to be located in the testis cords adjacent to the mesonephric rete region from which Meiosis Inducing Substance (Byskov \& Saxen, 1976) is believed to diffuse into the gonad. The great majority of XX $S x r /+$ germ cells, however, follow the male pathway of development, entering mitotic arrest as T-prospermatogonia before birth. Some of these differentiate into spermatogonia after birth, but subsequently they degenerate, and never enter meiosis or undergo spermatogenesis (Cattanach et al., 1971).

An analysis of the activity of an X-coded enzyme, hypoxanthine phosphoribosyl transferase (HPRT: EC 2.4.2.8), in XX, XO and XY fetal germ cells (Monk \& McLaren, 1981), has suggested that only one $\mathrm{X}$ chromosome is expressed in XX germ cells at $11 \frac{1}{2}$ days post coitum (p.c.), soon after colonization of the genital ridges. At $12 \frac{1}{2}$ and $13 \frac{1}{2}$ days p.c., however, the silent $\mathrm{X}$ chromosome is again expressed, so that $\mathrm{XX}$ germ cells show significantly higher activity than do XY and XO germ cells. At $13 \frac{1}{2}$ days p.c., germ cells are for the first time observed in the leptotene stage of meiotic prophase in the ovary. Following this, the female germ cells show a dramatic further increase in the activity of the $\mathrm{X}$-coded enzyme, associated with progress through meiotic prophase.

$\mathrm{XX}$ germ cells developing as prospermatogonia in the fetal Sex-reversed testis would not be expected to show the increase in X-coded enzyme activity that is a consequence of progress through meiotic prophase. Whether they show the higher HPRT activity associated with reactivation of the silent $\mathrm{X}$-chromosome, as XX germ cells in the ovary do, is investigated in the present paper. 


\section{Materials and Methods}

A stock of mice segregating for $S x r$ was obtained from $\mathrm{Dr}$ B. M. Cattanach (M.R.C. Radiobiology Unit, Harwell, U.K.). $S x r /+\mathrm{XY}$ males were identified by test-mating to females carrying an $\mathrm{X}$-linked coat pattern marker, and were then paired with females of the randomly bred $Q$ strain. The stock was kept on a reversed light/dark regimen (lights off 10:00-18:00 h), and females were inspected each morning for vaginal plugs. For purposes of dating the pregnancies, coitus was assumed to have taken place at the midpoint of the previous dark cycle, i.e. 14:00 h on the previous day. Pregnant females were killed between 10:00 and 15:00 h 14-16 days after the presumed day of coitus.

Embryos were dissected out of the uterus and sexed by examination of the gonads under a dissecting microscope. To detect sex chromatin, the amnion of each embryo was removed and fixed in methanol:acetic acid $(3: 1 \mathrm{v} / \mathrm{v})$. After about $30 \mathrm{~min}$, the fixative was removed and 3 drops of $60 \%$ acetic acid were added. The cell suspension was agitated gently for about $30 \mathrm{sec}$, air-dried on a clean slide at $60^{\circ} \mathrm{C}$ and left for at least $1 \mathrm{~h}$. The slides were then stained with toluidine blue in borax for $5 \mathrm{~min}$ at $60^{\circ} \mathrm{C}$, rinsed with distilled water and allowed to dry before examination (P. S. Burgoyne, personal communication).

The two gonads from each embryo were placed in PB1 (Whittingham \& Wales, 1969) containing $0.4 \%$ polyvinylpyrrolidone instead of albumin (PB 1/PVP) and mashed with a needle. The cells released were transferred to PB1/PVP in an agar-coated dish, and the large round germ cells were collected in batches of approximately 100 in $5 \mu$, and stored at $-70^{\circ} \mathrm{C}$ in $10 \mu \mathrm{l}$ capillary tubes. Extracts were prepared by freeze-thawing three times, followed by centrifugation. Approximately $4 \mu \mathrm{l}$ supernatant of each sample were transferred to $50 \mu \mathrm{l}$ of reaction mix at $37^{\circ} \mathrm{C}$ for $3 \mathrm{~h}$ to assay the activities of the X-coded enzyme HPRT, and the autosomal enzyme, adenine phosphoribosyl transferase (APRT: EC 2.4.2.7) (see Monk \& Harper, 1978, for details of the reaction). The reaction mix contained $\left[{ }^{3} \mathrm{H}\right]$ guanine $(10 \mu \mathrm{M}$, sp. act. 700 $\mathrm{Ci} / \mathrm{mol}),\left[{ }^{14} \mathrm{C}\right]$ adenine $(10 \mu \mathrm{M}$, sp. act. $276 \mathrm{Ci} / \mathrm{mol})$, phosphoribosyl pyrophosphate $(2 \mathrm{mM})$, magnesium chloride $(5 \mathrm{mM})$ and phosphate buffer $\left(50 \mathrm{mM} \mathrm{pH} \mathrm{7 \cdot 4).}\left[{ }^{3} \mathrm{H}\right]\right.$ Guanine and $\left[{ }^{14} \mathrm{C}\right]$ adenine were obtained from the Radiochemical Centre, Amersham, U.K. The reaction products, $\left[{ }^{3} \mathrm{H}\right]$ guanine monophosphate and $\left[{ }^{14} \mathrm{C}\right]$ adenine monophosphate, were determined in a Packard scintillation counter. The results were expressed as a ratio of HPRT:APRT, thus monitoring $\mathrm{X}$ chromosome: autosome dosage and eliminating sampling errors.

\section{Results}

The HPRT : APRT ratios were compared in germ cells from XX $q, \mathrm{XY} \delta^{\star}$ and $\mathrm{XX} S x r /+\delta^{\star}$ embryos at 15 and 16 days post coitum (Table 1). The female germ cells showed significantly higher values than did either group of male germs cells, as expected from the findings of Monk \&

Table 1. HPRT : APRT ratios in germ cells from XX ovaries, and XY and XX $S x r /+$ testes of mice at 15 and 16 days p.c.

\begin{tabular}{|c|c|c|c|c|c|c|}
\hline \multirow[b]{2}{*}{$\begin{array}{l}\text { Days } \\
\text { p.c. }\end{array}$} & \multirow[b]{2}{*}{ Litter } & \multicolumn{3}{|c|}{ Constitution of embryos } & \multirow{2}{*}{$\begin{array}{l}\text { Weighted mean } \\
\text { difference } \\
(b-a)\end{array}$} & \multirow[b]{2}{*}{ Significance } \\
\hline & & XXף & $\begin{array}{l}\mathrm{XY}{ }^{\circ} \\
\text { (a) }\end{array}$ & $\begin{array}{c}\mathrm{XX} S x r /+\delta \\
\text { (b) }\end{array}$ & & \\
\hline 15 & $\begin{array}{l}1 \\
2\end{array}$ & $\begin{array}{l}1.564 \pm 0.131(3) \\
1.301 \pm 0.129(3)\end{array}$ & $\begin{array}{l}0.741 \pm 0.029(5) \\
0.616 \pm 0.067(3)\end{array}$ & $\begin{array}{c}0.891 \pm 0.037(2) \\
1.003(1)\end{array}$ & $+0.232 \pm 0.062$ & $P<0.01$ \\
\hline 16 & $\begin{array}{l}1 \\
2\end{array}$ & $\begin{array}{l}1.173 \pm 0.009(2) \\
1.893 \pm 0.071\end{array}$ & $\begin{array}{c}0.467(1) \\
0.573 \pm 0.033(8)\end{array}$ & $\begin{array}{l}0.593 \pm 0.033(4) \\
0.904 \pm 0.053(3)\end{array}$ & $+0.367 \pm 0.073$ & $P<0.001$ \\
\hline
\end{tabular}

The data are logarithmically transformed, mean \pm s.e.m., number of embryos in parentheses. 
McLaren (1981), while the XX $S x r /+$ male values were significantly higher than the XY male values.

The higher HPRT: APRT values found in XX $S x r /+$ male compared with XY male germ cells could be due to reactivation of the inactive $\mathrm{X}$ chromosome, or to the increase associated with meiotic prophase because some of the XX germ cells enter meiosis in the XX $S x r /+$ testis at the same time as do XX germ cells in an ovary (McLaren, 1981). The meiotic germ cells in the fetal testis are always located adjacent to the mesonephric rete. In the next experiment, 16-day p.c. fetal gonads were therefore bisected so as to separate a 'rete' and a 'non-rete' half and germ cells from the two halves were isolated and assayed separately. Table 2 shows that there was no difference between the HPRT : APRT ratios from the two halves in the XX female or XY male germ cells; in XX $S x r /+$ male germ cells the ratios were higher in the 'rete' half, but the difference failed to reach the $5 \%$ level of significance even allowing for the fact that it was in the expected direction.

Table 2. HPRT : APRT ratios in germ cells from 'rete' and 'non-rete' halves of XX ovaries, and $\mathrm{XY}$ and $\mathrm{XX} S x r /+$ testes of mice at 16 days p.c.

\begin{tabular}{|c|c|c|c|}
\hline & \multicolumn{3}{|c|}{ Constitution of embryos } \\
\hline & $\mathrm{XX}$ 우 & $\mathrm{XY} ठ$ & $\mathrm{XX} S x r /+\sigma$ \\
\hline No. of embryos & 6 & 16 & 10 \\
\hline 'Rete' half $(\mathrm{a})^{*}$ & $1.729 \pm 0.062$ & $0.895 \pm 0.027$ & $1.251 \pm 0.055$ \\
\hline 'Non-rete' half* (b) & $1.823 \pm 0.056$ & $0.858 \pm 0.035$ & $1.170 \pm 0.052 \ddagger$ \\
\hline Difference $(a-b) \dagger$ & $-0.094 \pm 0.097$ & $+0.037 \pm 0.040$ & $+0.081 \pm 0.046$ \\
\hline$P$ & $>0.5$ & $>0.5$ & $0.1-0.2$ \\
\hline
\end{tabular}

If the increase in the HPRT:APRT ratio in $\mathrm{XX} S x r /+$ germ cells was due to $\mathrm{X}$-chromosome reactivation, it should be detectable at $13 \frac{1}{2}$ days p.c. (Monk \& McLaren, 1981). Two 14-day litters were therefore studied. Only germ cells from the half of the testis opposite to the rete were taken, in case the difference between 'rete' and 'non-rete' halves was real. The ratios in $\mathrm{XX} \mathrm{Sxr} /+$ male germ cells were significantly higher than those in XY male germ cells (Table 3).

The results from these three experiments are summarized in Text-fig. 1.

To investigate changes in HPRT : APRT ratio associated with meiotic prophase, but in the absence of $\mathrm{X}$-chromosome reactivation, we examined four litters from XO mothers mated with normal XY males (Table 4). HPRT : APRT ratios were significantly higher in XO than in XY germ cells. The $\mathrm{XO}$ tended to be lower than the $\mathrm{XX}$ values, consistent with a gene dosage effect following reactivation. However, the difference between $\mathrm{XO}$ and $\mathrm{XX}$ values was not significant on the numbers examined; the ratios in female germ cells are changing very rapidly at this time (Monk \& McLaren, 1981), and the standard errors of the estimates were very large.

Table 3. HPRT: APRT ratios in germ cells from 'non-rete' halves of $X X$ ovaries, and $X Y$ and XX Sxr/+testes of mice at 14 days p.c.

\begin{tabular}{ccccc}
\hline Litter & $\mathrm{XX} \subsetneq$ & $\begin{array}{c}\mathrm{XY} \sigma \\
(\mathrm{a})\end{array}$ & $\begin{array}{c}\text { XX Sxr } /+\sigma \\
(\mathrm{b})\end{array}$ & $\begin{array}{c}\text { Weighted mean } \\
\text { difference } \\
(\mathrm{b}-\mathrm{a})\end{array}$ \\
\hline 1 & $0.487 \pm 0.017(2)$ & $0.125 \pm 0.030(3)$ & $0.243(1)$ & $+0.208 \pm 0.083^{*}$ \\
2 & $0.995 \pm 0.025(4)$ & $0.245 \pm 0.060(9)$ & $0.477 \pm 0.039(4)$ & \\
\hline
\end{tabular}

The values are mean \pm s.e.m. for the no. of embryos in parentheses after logarithmic transformation of the data.

$* P<0.05$. 


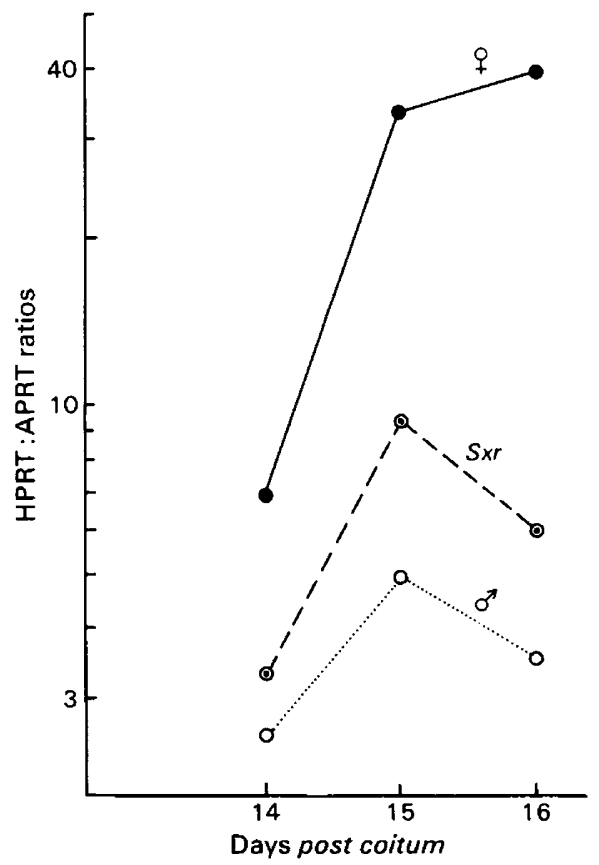

Text-fig. 1. Mean HPRT : APRT activity ratios as a function of gestational age in germ cells

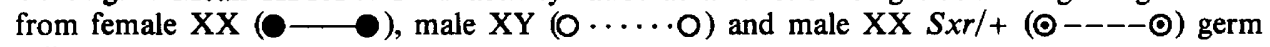
cells.

Table 4. HPRT : APRT ratios in germ cells from $X X$ and $X O$ ovaries and $X Y$ testes, 14.5 and $15 \cdot 5$ days $p . c$.

\begin{tabular}{cccccc}
\hline & & \multicolumn{3}{c}{ Constitution of embryos } & Weighted mean \\
\cline { 3 - 6 } $\begin{array}{c}\text { Days } \\
\text { p.c. }\end{array}$ & Litter & $\mathrm{XX} \subsetneq$ & $\begin{array}{c}\text { XO९ } \\
(\mathrm{a})\end{array}$ & $\begin{array}{c}\text { XY } \\
(\mathrm{b})\end{array}$ & $\begin{array}{c}\text { difference } \\
(\mathrm{a}-\mathrm{b})\end{array}$ \\
\hline 14.5 & 1 & - & $1.079 \pm 0.124(3)$ & $0.638 \pm 0.107(2)$ & \\
15.5 & 1 & $1.502(1)$ & $0.840 \pm 0.010(2)$ & $0.460 \pm 0.078(2)$ & $0.545 \pm 0.112^{*}$ \\
& 2 & $1.628 \pm 0.18(2)$ & $1.284(1)$ & $0.745 \pm 0.027(2)$ & \\
& 3 & $1.622 \pm 0.082(2)$ & $1.863(1)$ & $0.732(1)$ & \\
\hline
\end{tabular}

The values are mean \pm s.e.m. for the no. of embryos in parentheses after logarithmic transformation. * $P<0.001$.

\section{Discussion}

Our earlier demonstration that XO germ cells have significantly lower HPRT : APRT ratios than do XX germ cells when both have entered meiotic prophase (Monk \& McLaren, 1981) suggested strongly that the silent $\mathrm{X}$ chromosome is reactivated in the $\mathrm{XX}$ cells. The difference, about 2-fold, is unlikely to be due to delayed development of the XO germ cells, because

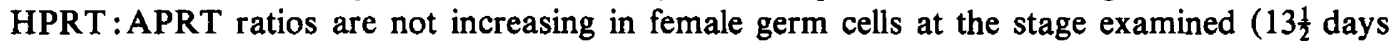
p.c.). Reactivation of the silent $X$ is confirmed by the present finding that HPRT:APRT ratios are significantly higher in $\mathrm{XX} S x r /+$ than $\mathrm{XY}$ prospermatogonia. The greatest difference observed is again about 2-fold, which is consistent with an X-chromosome dosage effect.

By $15 \frac{1}{2}$ days p.c., the HPRT:APRT ratio in XX oocytes reaches a level considerably more than twice that in XY prospermatogonia, owing to an increase in HPRT activity, and 
subsequently declines (Monk \& McLaren, 1981). If this were merely the result of reactivation of the silent $\mathrm{X}$ chromosome in the XX germ cells, it would indicate a temporary 'over-shoot' of HPRT activity, such that a doubling of effective gene dosage unbalanced the control mechanisms of the cell, leading to a disproportionately large increase in enzyme activity. Alternatively, the very high values seen in $\mathrm{XX}$ oocytes could be due to some change in HPRT activity associated with the zygotene and pachytene stages of meiotic prophase, additional to and independent of the $\mathrm{X}$-chromosome dosage effect. The present finding, that the ratio in XX prospermatogonia is about double that in XY prospermatogonia and falls well short of that in $\mathrm{XX}$ oocytes, is not consistent with the 'over-shoot' hypothesis, which might be expected to operate in whatever cell type reactivation occurs. We conclude therefore that the high values characteristic of $\mathrm{XX}$ oocytes must reflect some change in gene activity associated with meiosis.

This conclusion is supported by the significant difference in HPRT:APRT ratio between $\mathrm{XO}$ and XY germ cells at 14-15 days p.c. (Table 4). Since XO germ cells also enter meiosis in the fetal ovary, they also show the increase in HPRT:APRT ratio associated with meiotic prophase, even though they do not show the increase arising from $\mathrm{X}$-chromosome reactivation (Monk \& McLaren, 1981).

It seems unlikely on quantitative grounds that the increased HPRT:APRT values in XX $\mathrm{Sxr} /+$ germ cells could arise from the subpopulation that has entered meiosis, which is located in that part of the gonad adjacent to the mesonephric rete (McLaren, 1981). At 14-16 days p.c.. the mouse testis contains tens of thousands of germ cells; the subpopulation entering meiosis has not been counted, but appears to number tens or at most hundreds (A. McLaren, unpublished observation), and the increase in HPRT:APRT ratio due to meiosis as such does not exceed 10 -fold. A difference at most of $10 \%$ in HPRT : APRT ratio between germ cells from the 'rete' and the 'non-rete' half might be expected from this source; a non-significant difference of this order was indeed observed (Table 2).

The most intriguing conclusion from the present findings is that reactivation of the silent $\mathrm{X}$ chromosome is not necessarily linked with entry into meiotic prophase. We earlier observed that reactivation preceded the appearance in the ovary of germ cells in leptotene (Monk \& McLaren, 1981); it now appears that germ cells carrying two $\mathrm{X}$ chromosomes will undergo reactivation whether they are destined to follow the female or the male pathway of differentiation. The presence of more than one $\mathrm{X}$ chromosome is known to be incompatible with spermatogenesis (Lyon, 1974; Burgoyne, 1978); therefore, although an XX germ cell with both X chromosomes 'switched on' does not have to develop as an oocyte and enter meiotic prophase before birth, it seems that it is debarred from undergoing spermatogenesis and entering meiotic prophase after birth.

\section{References}

Burgoyne, P.S. (1978) The role of the sex chromosomes in mammalian germ cell differentiation. Annls Biol. anim. Biochim. Biophys. 18, 317-325.

Byskov, A.G. \& Saxen, L. (1976) Induction of meiosis in fetal mouse testis in vitro. Devl Biol. 52, 193-200.

Cattanach, B.M., Pollard, C.E. \& Hawkes, S.G. (1971) Sex-reversed mice: XX and XO males. Cytogenetics 10, 318-337.

Lyon, M.F. (1974) Sex chromosome activity in germ cells. In Physiology and Genetics of Reproduction A, pp. 63-71. Eds E. M. Coutinho \& F. Fuchs. Plenum, New York.
McLaren, A. (1981) The fate of germ cells in the testis of fetal Sex-reversed mice. J. Reprod. Fert. 61, 461467.

Monk, M. \& Harper, M. (1978) X-chromosome activity in preimplantation mouse embryos from $\mathrm{XX}$ and $\mathrm{XO}$ mothers. J. Embryol. exp. Morph. 46, 53-64.

Monk, M. \& McLaren, A. (1981) X-chromosome activity in fetal germ cells of the mouse. J. Embryol. exp. Morph. 63, 75-84.

Whittingham, D.G. \& Wales, R.G. (1969) Storage of two cell mouse embryos in vitro. Aust. J. biol. Sci. 22, 1065-1068. 